\title{
Perbedaan Perkembangan Motorik Antara Anak Taman Kanak-Kanak di Daerah Perkotaan dan Pedesaan Menggunakan Instrument Denver II
}

\author{
Aulia $^{(1)}$, Saiful Batubara ${ }^{(2)}$ \\ Fakultas Kedokteran Universitas Islam Sumatera Utara ${ }^{(1)(2)}$ \\ Aulia.fuad.001@gmail.com, Saifulbatubara24@gmail.com
}

\begin{abstract}
ABSTRAK
Perkembangan motorik adalah perkembangan kontrol gerakan tubuh melalui aktivitas saraf utama, saraf samping, dan otot. Setiap anak adalah individu yang unik, karena faktor pewarisan dan lingkungan yang berbeda, perkembangan dan pencapaian kemampuan juga berbeda, tetapi akan mengikuti pola umum. Tujuan dari penelitian ini adalah untuk menemukan perbedaan dalam aspek motorik anak prasekolah yang merupakan anak-anak di taman kanak-kanak yang berbeda di kota dan pedesaan menggunakan instrumen Denver II. Penelitian ini menggunakan metode perbandingan Cross-Sectional dengan sampel diambil sesuai dengan metode Purposive sampling di mana sampel untuk setiap populasi ditetapkan untuk 50 anak. Dengan demikian total sampel adalah 100 anak-anak dari TK kota dan pedesaan. Hasil penelitian ini menggunakan uji MannWhitney, dimana hasil uji Mann-Whitney dalam pengembangan motor lunak didapat dari skor $\mathrm{p}=0,393$, karena signifikansi $\mathrm{p}=0,393>0,05$, dapat disimpulkan bahwa tidak ada perbedaan dalam pengembangan motorik lunak antara anak-anak di TK kota dan pedesaan. Dan hasil analisis uji Mann-Whitney dalam pengembangan motorik keras mendapat skor $\mathrm{p}=0,648>\mathrm{p} 0,05$, dapat disimpulkan bahwa tidak ada perbedaan perkembangan motorik keras antara anak-anak di TK kota dan pedesaan. Penelitian ini diharapkan dapat meningkatkan pengetahuan dan penambahan dalam bidang kesehatan. Selain itu, diharapkan dari guru prent dan TK untuk selalu mengawasi perkembangan motorik anak-anak dengan memperhatikan faktor-faktor yang mempengaruhinya.
\end{abstract}

Kata Kunci : Perkembangan Motorik, Taman Kanak-kanak, Instrumen Denver II

\begin{abstract}
Motor development is a development of body movement control through main nerve activity, side nerve, and muscle. Every children is a uniqe individual, because of the inheritance factor and different environment, the development and ability achievement is also different, but will follow the general pattern. The aim of this research is to find the difference in the preschool childrens' motor aspect which are the children in different kindergartens in the city and countryside using the Denver II instrument. This research is using Cross-Sectional comparative method with the sample taken according to the Purposive sampling method where the sample for each populations is set for 50 children. Thus the total sample will be 100 children from the city and countryside kindergarten. The result of this research is using the Mann-Whitney test, where the the result of Mann-Whitney test in soft motor development gotten from the score $p=0,393$, because the significance of $p=0,393>0,05$, it can be concluded that there are no difference in in soft motor development between the children in the city and countryside kindergarten. And the result of Mann-Whitney test analysis in hard motor development received score $p=0,648>p 0,05$, it can be concluded that there are no hard motor development difference between the children in the city and countryside kindergarten. This research is expected to be able to increase knowledge and addition in the health subject. Also, it is expected from the prents and kindergarten teachers to always watch over the children's motor development with watching the factors that affect it.
\end{abstract}

Keywords : Motorik Development, Kindergartens, Denver II 
Aulia, Saiful B : Perbedaan Perkembangan Motorik Antara Anak Taman Kanak-Kanak di Daerah Perkotaan dan Pedesaan Menggunakan Instrumen Denver II

\section{PENDAHULUAN}

\section{Latar Belakang}

Perkembangan adalah bertambahnya kemampuan (skill) struktur dan fungsi tubuh yang lebih kompleks, dalam pola yang teratur dan dapat diramalkan, sebagai hasil dari proses pematangan/maturitas. Setiap anak adalah individu yang unik, karena faktor bawaan dan lingkungan yang berbeda, maka pertumbuhan dan pencapaian kemampuan perkembangannya juga berbeda, tetapi akan tetap mengikuti patokan umum WHO (World Health Organitation) tahun 2007 melaporkan bahwa 5-25\% dari anak-anak usia dini menderita disfungsi otak minor, termasuk gangguan perkembangan motorik halus. Depkes RI (2006), bahwa 0,4 juta (16\%) balita di Indonesia mengalami gangguan perkembangan, baik perkembangan motorik halus dan kasar, gangguan pendengaran, kecerdasan kurang dan keterlambatan bicara $^{2}$. Hasil penelitian tahun 2012 di kecamatan wara utara kota Palopo didapati pencapaian tugas perkembangan anak masing-masing sektor adalah untuk motorik kasar menunjukkan hasil normal $80,9 \%$, caution $17,0 \%$, dan delay $2,1 \%$, untuk motorik halus menunjukkan hasil advance 2,1\%, normal 78,7\%, caution $17,0 \%$ dan delay $2,1 \%$, untuk bahasa menunjukkan hasil advance $10,6 \%$, normal 66,0\%, caution 19,1\% dan delay $4,3 \%$, untuk personal sosial menunjukkan hasil advance 4,3\%, normal 72,3\%, caution $19,1 \%$ dan delay $4,3 \%{ }^{2}$. Perkembangan anak membutuhkan stimulasi. Anak yang mendapat stimulasi yang terarah dan teratur lebih cepat berkembang dibandingkan dengan anak yang kurang atau tidak mendapat stimulasi. Masa prasekolah (preschool/early childhood) adalah anak yang berusia 3 sampai dengan 6 tahun. Pada masa ini terdapat kemajuan perkembangan motorik dan fungsi ekskresi. Aktivitas fisik bertambah serta keterampilan dan proses berfikir meningkat Perkembangan motorik yang terlambat berarti perkembangan motorik yang berada di bawah normal umur anak. Hal itu mungkin timbul dari kerusakan otak pada waktu lahir atau kondisi pralahir yang tidak menguntungkan atau lingkungan yang tidak menyenangkan pascalahir. Akan tetapi, keterlambatan lebih sering di sebabkan oleh kurangnya kesempatan untuk mempelajari keterampilan motorik, perlindungan orang tua yang berlebihan, atau kurangnya motivasi anak untuk mempelajarinya Skrining perkembangan merupakan hal yang sangat penting dalam upaya meningkatkan kualitas hidup anak. Pemantauan dan skrining perkembangan anak sangat penting karena dengan pemantauan yang baik, dapat dilakukan deteksi dini kelainan perkembangan anak, sehingga intervensi dini dapat dilakukan dan tumbuh kembang anak dapat lebih optimal sesuai dengan kemampuan genetiknya. Salah satu instrumen untuk skrining yang dipakai secara internasional adalah DDST (Denver Developmental Screening Test) disebut sebagai Denver II dengan menggunakan pass-fail ratings pada 4 ranah perkembangan yaitu personal-social, fine motor adaptive, language, dan gross motor untuk anak sejak lahir hingga usia 6 tahun.

\section{Perumusan Masalah}

Pemantauan dan skrining perkembangan anak sangat penting karena dengan pemantauan yang baik, dapat dilakukan deteksi dini kelainan perkembangan anak, sehingga intervensi dini dapat dilakukan dan tumbuh kembang anak dapat lebih optimal sesuai dengan kemampuan genetiknya. Salah satu instrumen untuk skrining yang dipakai secara internasional adalah DDST (Denver Developmental Screening Test) disebut sebagai Denver II dengan menggunakan pass-fail ratings pada 4 ranah perkembangan yaitu personal-social, fine motor adaptive, language, dan gross motor untuk anak sejak lahir hingga usia 6 tahun.

\section{Tujuan Penelitian}

Tingkat dan kecepatan perkembangan seorang anak adalah hasil akhir dari berbagai faktor, yang banyak dari faktor-faktor tersebut tidak berkaitan dengan kemampuan mental genetik 
anak, misalnya ada tidaknya penyakit kronis, kendala fisik atau sensorik, dan kualitas lingkungan tempat ia tumbuh Secara umum tumbuh kembang dipengaruhi oleh dua faktor utama yang meliputi faktor genetik dan faktor lingkungan. Faktor lingkungan merupakan faktor yang memegang peranan penting dalam menentukan tercapai atau tidaknya potensi yang sudah dimiliki ${ }^{8}$. Lingkungan yang baik akan memungkinkan tercapainya potensi genetik, sedangkan yang tidak baik akan menghambatnya Stimulasi dari lingkungan merupakan hal yang penting untuk tumbuh kembang anak. Anak yang mendapatkan stimulasi yang terarah dan teratur akan lebih cepat berkembang dibandingkan anak yang kurang/tidak mendapat stimulasi Sedikit banyak ada beberapa hal yang menjadi penyebab perbedaan perkembangan motorik dan aktivitas sehari-hari antara anak yang tinggal di daerah perkotaan dibandingkan dengan anak yang tinggal di daerah perdesaan antara lain faktor yang berkenaan dengan faktor lingkungan seperti pada perilaku sedentary dan lainnya. Tujuan penelitian ini diharapkan mampu memberikan informasi tentang perbedaan pada aspek motorik anak di taman kanak-kanak yang berada di perkotaan dan perdesaan menggunakan instrumen Denver II

\section{Manfaat Penelitian}

Perkembangan motorik merupakan perkembangan kontrol pergerakan badan melalui koordinasi aktivitas saraf pusat, saraf tepi, dan otot. Perkembangan motorik dibagi menjadi dua, yaitu perkembangan motorik kasar dan motorik halus. Motorik Kasar (Gross Motor)Perkembangan motorik kasar melibatkan otot-otot besar meliputi pergerakan gerakan kepala, badan, keseimbangan, dan pergerakan Motorik Halus (Fine Motor) Perkembangan motorik halus merupakan aspek yang berhubungan dengan kemampuan anak untuk mengamati sesuatu, melakukan gerakan yang melibatkan bagian-bagian tubuh tertentu saja dan dilakukan otot-otot kecil, tetapi melakukan koordinasi yang cermat, misalnya kemampuan untuk menggambar, memegang sesuatu benda dan lain-lain.

\section{METODE PENELITIAN}

Penelitian ini menggunakan metode analitik komparatif dengan pendekatan cross sectional. Penelitian ini dilakukan pada Bulan Januari 2018 sampai Bulan Februari 2018 di TK Nur Aisyah Kota Medan dan TK Cerdas Bangsa Desa Delitua, Kabupaten Deli Serdang. Penentuan besarnya sampel dalam penelitian ini menggunakan metode purposive sampling dengan besar sampel 100 anak dimana 50 anak pada TK Nur Aisyah dan 50 anak pada TK Cerdas Bangsa. Analisis data dilakukan dengan Analisa Univariat yaitu menganalisis distribusi frekuensi berdasarkan jenis kelamin dan umur anak dan Analisa Bivariat dilakukan dengan menggunakan uji Mann-Whitney serta Instrumen yang digunakan pada penelitian ini adalah Denver II.

\section{HASIL DAN PEMBAHASAN}

Analisis Univariat

Analisis univariat merupakan analisis yang bertujuan untuk menjelaskan atau mendeskripsikan karakteristik masing-masing variabel penelitian. Oleh karena variabel penelitian diukur dalam bentuk kategorik ordinal, maka hasil perhitungan untuk analisis univariat berupa distribusi frekuensi.

\section{Jenis Kelamin}

Dari hasil rekapitulasi data berdasarkan jenis kelamin, didapatkan hasil pada tabel 1 dan tabel 2 dibawah ini : 
Aulia, Saiful B : Perbedaan Perkembangan Motorik Antara Anak Taman Kanak-Kanak di Daerah Perkotaan dan Pedesaan Menggunakan Instrumen Denver II

\begin{tabular}{|c|c|c|}
\hline $\begin{array}{c}\text { Jenis } \\
\text { Kelamin }\end{array}$ & Frekuensi & $\begin{array}{c}\text { Persen } \\
(\boldsymbol{\%})\end{array}$ \\
\hline Laki-laki & 27 & 54 \\
\hline Perempuan & 23 & 46 \\
\hline Total & $\mathbf{5 0}$ & $\mathbf{1 0 0}$ \\
\hline
\end{tabular}

Tabel 1 Distribusi karakteristik jenis kelamin pada anak TK di daerah perkotaan

Dari Tabel 1 menunjukkan bahwa distribusi jenis kelamin anak TK di daerah perkotaan yang berjenis kelamin laki-laki yaitu sebanyak 27 orang anak (54\%) dan yang berjenis kelamin perempuan yaitu sebanyak 23 orang anak (46\%).

\begin{tabular}{|c|c|c|}
\hline $\begin{array}{c}\text { Jenis } \\
\text { Kelamin }\end{array}$ & Frekuensi & $\begin{array}{c}\text { Persen } \\
(\boldsymbol{\%})\end{array}$ \\
\hline Laki-laki & 26 & 52 \\
\hline Perempuan & 24 & 48 \\
\hline Total & $\mathbf{5 0}$ & $\mathbf{1 0 0}$ \\
\hline
\end{tabular}

\section{Tabel 2 Distribusi karakteristik jenis kelamin pada anak TK di daerah perdesaan}

Dari Tabel 2 menunjukkan bahwa distribusi jenis kelamin anak TK di daerah perdesaan sebagian besar berjenis kelamin laki-laki yaitu sebanyak 26 anak (52\%) dan yang berjenis kelamin perempuan yaitu sebanyak 24 anak (48\%).

\section{b. Umur}

Dari hasil rekapitulasi data berdasarkan umur, didapatkan hasil pada tabel 3 dan tabel 4 dibawah ini :

\begin{tabular}{|c|c|c|}
\hline $\begin{array}{c}\text { Umur } \\
\text { (bulan) }\end{array}$ & Frekuensi & $\begin{array}{c}\text { Persen } \\
(\boldsymbol{\%})\end{array}$ \\
\hline $48-54$ & 1 & 2 \\
\hline $55-60$ & 3 & 6 \\
\hline $61-66$ & 27 & 54 \\
\hline $67-72$ & 19 & 38 \\
\hline Total & $\mathbf{5 0}$ & $\mathbf{1 0 0}$ \\
\hline
\end{tabular}


Aulia, Saiful B : Perbedaan Perkembangan Motorik Antara Anak Taman Kanak-Kanak di Daerah Perkotaan dan Pedesaan Menggunakan Instrumen Denver II

Tabel 3 Distribusi karakteristik umur pada anak TK di daerah perkotaan

Dari Tabel 3 menunjukkan bahwa distribusi umur anak TK di daerah perkotaan yaitu anak yang berumur 48-54 bulan sebanyak 1 anak (2\%), anak yang berumur 55-60 bulan sebanyak 3 anak (6\%), anak yang berumur 61-66 bulan sebanyak 27 anak (54\%), dan anak yang berumur 67-72 bulan sebanyak 19 anak (38\%).

\begin{tabular}{|c|c|c|}
\hline $\begin{array}{c}\text { Umur } \\
\text { (bulan) }\end{array}$ & Frekuensi & $\begin{array}{c}\text { Persen } \\
(\boldsymbol{\%})\end{array}$ \\
\hline $48-54$ & 1 & 2 \\
\hline $55-60$ & 2 & 4 \\
\hline $61-66$ & 16 & 32 \\
\hline $67-72$ & 31 & 62 \\
\hline Total & $\mathbf{5 0}$ & $\mathbf{1 0 0}$ \\
\hline
\end{tabular}

Tabel 4 Distribusi karakteristik umur pada anak TK di daerah Perdesaan

Dari Tabel 4 menunjukkan bahwa distribusi umur anak TK di daerah perdesaan yaitu anak yang berumur 48-54 bulan sebanyak 1 anak (2\%), anak yang berumur 55-60 bulan sebanyak 2 anak (4\%), anak yang berumur 61-66 bulan sebanyak 16 anak (32\%), dan anak yang berumur 67-72 bulan sebanyak 31 anak (62\%).

\section{Analisis Bivariat}

Analisis bivariat dilakukan untuk mengetahui dan menganalisa ada tidaknya perbedaan pencapaian tugas perkembangan motorik anak taman kanak-kanak didaerah perkotaan dan didaerah perdesaan.

\section{a. Perkembangan Motorik Kasar}

Dari hasil rekapitulasi data berdasarkan pencapaian perkembangan motorik kasar, didapatkan hasil pada tabel 5 dan tabel 6 dibawah ini :

\begin{tabular}{|c|c|c|}
\hline $\begin{array}{c}\text { Motorik } \\
\text { Kasar }\end{array}$ & Frekuensi & $\begin{array}{c}\text { Persen } \\
(\boldsymbol{\%})\end{array}$ \\
\hline Normal & 47 & 94 \\
\hline Suspek & 3 & 6 \\
\hline Abnormal & 0 & 0 \\
\hline Total & $\mathbf{5 0}$ & $\mathbf{1 0 0}$ \\
\hline
\end{tabular}

Tabel 5 Distribusi Perkembangan Motorik Kasar Anak TK didaerah Perkotaan 
Aulia, Saiful B : Perbedaan Perkembangan Motorik Antara Anak Taman Kanak-Kanak di Daerah Perkotaan dan Pedesaan Menggunakan Instrumen Denver II

Dari Tabel 5 menunjukkan bahwa distribusi perkembangan motorik kasar anak TK didaerah perkotaan menunjukkan bahwa 47 anak atau sebesar 94\% dari seluruh sampel digolongkan normal, sebanyak 3 orang (6\%) digolongkan suspek dan tidak ada $(0 \%)$ yang digolongkan abnormal dari seluruh sampel.

\begin{tabular}{|c|c|c|}
\hline $\begin{array}{c}\text { Motorik } \\
\text { Kasar }\end{array}$ & Frekuensi & $\begin{array}{c}\text { Persen } \\
(\mathbf{\%})\end{array}$ \\
\hline Normal & 48 & 96 \\
\hline Suspek & 2 & 4 \\
\hline Abnormal & 0 & 0 \\
\hline Total & $\mathbf{5 0}$ & $\mathbf{1 0 0}$ \\
\hline
\end{tabular}

\section{Tabel 6 Distribusi Perkembangan Motorik Kasar Anak TK didaerah Perdesaan}

Dari Tabel 6 menunjukkan bahwa distribusi perkembangan motorik kasar anak TK didaerah perdesaan menunjukkan bahwa 48 anak atau sebesar $96 \%$ dari seluruh sampel digolongkan normal, sebanyak 2 orang (6\%) digolongkan suspek dan tidak ada (0\%) yang digolongkan abnormal dari seluruh sampel.

\section{b. Perkembangan Motorik Halus}

Dari hasil rekapitulasi data berdasarkan pencapaian perkembangan motorik halus, didapatkan hasil pada tabel 7 dan tabel 8 dibawah ini :

\begin{tabular}{|c|c|c|}
\hline $\begin{array}{c}\text { Motorik } \\
\text { Halus }\end{array}$ & Frekuensi & $\begin{array}{c}\text { Persen } \\
(\boldsymbol{\%})\end{array}$ \\
\hline Normal & 49 & 98 \\
\hline Suspek & 1 & 2 \\
\hline Abnormal & 0 & 0 \\
\hline Total & $\mathbf{5 0}$ & $\mathbf{1 0 0}$ \\
\hline
\end{tabular}

\section{IV.PEMBAHASAN}

\section{a. Perbedaan perkembangan motorik kasar anak taman kanak-kanak didaerah} perkotaan dan didaerah perdesaan

Perkembangan motorik merupakan perkembangan kontrol pergerakan badan melalui koordinasi aktivitas saraf pusat, saraf tepi, dan otot. Perkembangan motorik dibagi menjadi dua, yaitu perkembangan motorik kasar dan motorik halus Hasil penelitian data frekuensi perkembangan motorik kasar terbagi dalam tiga kategori, yaitu normal dengan frekuensi 47 orang anak (94\%) pada daerah perkotaan dan 48 orang anak (96\%) pada daerah perdesaan, kategori suspek dengan frekuensi 3 orang anak $(6 \%)$ pada daerah 
perkotaan dan 2 orang anak (4\%) pada daerah perdesaan, serta ketegori abnomal dengan frekuensi $0(0 \%)$ pada kedua daerah. Dari hasil penelitian didapati perkembangan motorik kasar anak TK pada daerah perdesaan lebih baik daripada anak TK pada daerah perkotaan, namun secara signifikasi uji Mann-Whitney tidak didapati perbedaan yang signifikan dengan nilai $\mathrm{p}$ 0,648 yang artinya tidak ada perbedaan perkembangan motorik kasar antara anak TK daerah perkotaan dan anak TK daerah perdesaan. Hasil penelitian data frekuensi perkembangan motorik halus terbagi dalam tiga kategori, yaitu normal dengan frekuensi 48 orang anak (96\%) pada daerah perkotaan dan 46 orang anak (92\%) pada daerah perdesaan, kategori suspek dengan frekuensi 2 orang anak (4\%) pada daerah perkotaan dan 3 orang anak (6\%) pada daerah perdesaan, serta ketegori abnomal dengan frekuensi $0(0 \%)$ pada daerah perkotaan dan 1 orang anak $(2 \%)$ pada daerah perdesaan. Dari hasil penelitian didapati perkembangan motorik halus anak TK pada daerah perkotaan lebih baik daripada anak TK pada daerah perdesaan, namun secara signifikasi uji Mann-Whitney tidak didapati perbedaan yang signifikan dengan nilai $\mathrm{p}$ 0,393 yang artinya tidak ada perbedaan perkembangan motorik halus antara anak TK daerah perkotaan dan anak TK daerah perdesaan.

Hal ini menunjukkan bahwa daerah tempat tinggal yaitu daerah perkotaan dan perdesaan tidak mempengaruhi pencapaian perkembangan motorik kasar dan motorik halus anak. Hal ini berbeda dengan Soetjiningsih yang menyatakan bahwa faktor lingkungan tempat seorang anak mengalami tumbuh kembang, merupakan faktor yang sangat menentukan tercapai atau tidaknya potensi bawaan. Temuan pada penelitian ini berbeda kemungkinan dipengaruhi oleh letak perkotaan dan perdesaan yang tidak terlampau jauh yang hanya berjarak 30 menit dari daerah perkotaan. Hal ini sesuai dengan penelitian Fadlyana (2003) yang menyatakan daerah penelitian yaitu pola keterlambatan perkembangan anak pada daerah perkotaan dan daerah perdesaan, semakin ke pedesaan makin tinggi peluang untuk mengalami keterlambatan perkembangan Berbagai faktor lain seperti yang dikemukakan pada teori Piaget yang menekankan bahwa perkembangan tidak disebabkan oleh kematangan potensial keturunan atau kekuatan lingkungan saja namun interaksi antara keduanya serta pentingnya proses kematangan, pengalaman dengan lingkungan, latihan dan norma budaya. Disamping itu, tidak adanya perbedaan perkembangan motorik antara anak TK didaerah perkotaan dan daerah perdesaan dipengaruhi oleh banyak faktor lain yang mempengaruhi tahapan perkembangan diantaranya stimulasi dari lingkungan. Hal ini sesuai dengan Soetjiningsih (2013) bahwa stimulasi dari lingkungan merupakan hal yang penting untuk tumbuh kembang anak. Stimulasi tumbuh kembang dapat dilakukan dengan cara memberikan permainan atau bermain Taman kanak-kanak (TK) merupakan jenjang pendidikan formal anak usia dini dimana tidak ada mata pelajaran yang mengikat untuk siswa kecuali bermain. Jadi anak TK dari kedua kelompok tersebut sama-sama mendapatkan stimulasi perkembangan terutama perkembangan motorik kasar dan motorik halus dari sekolah yang dibimbing atau diasuh oleh guru sebagai pendidikan formal anak usia dini. Diketahui bahwa kompetensi guru taman kanak-kanak kini sudah mendapatkan standarisasi baik di daerah perkotaan dan daerah perdesaan pada kedua kelompok penelitian, hal ini dibuktikan dengan baiknya profil pendidikan dari kedua kelompok TK tersebut sehingga para guru dari kedua kelompok samasama mampu memberikan stimulasi yang baik terhadap pencapaian perkembangan motorik anak Dengan demikian, pencapaian perkembangan motorik anak TK didaerah perkotaan dan daerah perdesaan tidak mengalami perbedaan yang signifikan oleh karena terpenuhinya kebutuhan bermain sebagai salah satu stimuli terhadap perkembangan motorik anak. Hal ini sesuai dengan yang dikemukakan Hidayat (2008) bahwa pada anak yang mendapatkan atau terpenuhi kebutuhan bermainnya dapat terlihat pula adanya suatu pola perkembangan yang baik: Maka dari itu, hal ini memungkinkan tercapainya pencapaian perkembangan anak pada 
Aulia, Saiful B : Perbedaan Perkembangan Motorik Antara Anak Taman Kanak-Kanak di Daerah Perkotaan dan Pedesaan Menggunakan Instrumen Denver II

kedua TK yang diteliti adalah sama baiknya meskipun daerah tempat tinggal kedua subjek penelitian berbeda yaitu di daerah perkotaan dan di perdesaan.

\section{V.KESIMPULAN}

Berdasarkan hasil penelitian dan pembahasan, maka dapat disimpulkan:

1. Perkembangan motorik kasar anak TK di daerah perkotaan sebagian besar mencapai normal dengan frekuensi 47 anak atau sebesar 94\%.

2. Perkembangan motorik halus anak TK di daerah perkotaan sebagian besar mencapai normal dengan frekuensi 49 anak atau sebesar $98 \%$.

3. Perkembangan motorik kasar anak TK di daerah perdesaan sebagian besar mencapai normal dengan frekuensi 48 anak atau sebesar $96 \%$.

4. Perkembangan motorik halus anak TK di daerah perkotaan sebagian besar mencapai normal dengan frekuensi 46 anak atau sebesar $92 \%$.

5. Tidak ada perbedaan perkembangan motorik kasar antara anak taman kanak-kanak di daerah perdesaan dan perkotaan dengan $\mathrm{p}$ value $=0,648$.

6. Tidak ada perbedaan perkembangan motorik halus antara anak taman kanak-kanak di daerah perdesaan dan perkotaan dengan $\mathrm{p}$ value $=0,393$.

\section{DAFTAR PUSTAKA}

Soetjiningsih, Ranuh IG.N.G. Tumbuh Kembang Anak.Ed.2. Jakarta: EGC; 2013

Widati A, Syaiful Y, Rahmawati DW. Pengaruh Terapi Bermain:Origami Terhadap Perkembangan Motorik Halus dan Kognitif Anak Usia Prasekolah (4-5 tahun). Journal of Nerscommunity. 2012; 3(6): 16-29

Ardita V, Kadir A, Askar M. Deteksi Perkembangan Anak Berdasarkan DDST Di RW I Kelurahan Luminda Kecamatan Wara Utara Kota Palopo. 2012; 1(2) : 1-8

Hurlock EB. Perkembangan Anak. Ed.6. Jakarta: Erlangga; 2013

Narendra MB, Sularyo TS, Soetjiningsih, Suyitno H, Ranuh IG.N.G. Tumbuh Kembang Anak dan Remaja. Ed.1. Jakarta: Sagung Seto; 2008

Maryunani A. Ilmu Kesehatan Anak dalam Kebidanan. Jakarta: Trans Info Medika; 2010

Rudolph AM. Buku Ajar RUDOLPH. Ed.20. Jakarta: EGC; 2006

Hidayat AAA. Pengantar Ilmu Keperawatan Anak Untuk Pendidikan Kebidanan. Jakarta: Salemba Medika; 2008

Fadlyana E, Alisjahbanna A, Nelwan I, Noor M, Selly, Sofiatin Y. Pola Keterlambatan Perkembangan Balita di Daerah Pedesaan dan Perkotaan Bandung Serta Faktor-faktor Yang Mempengaruhinya. Sari Pediatri. 2003; 4(4) : 168-175

Hasan M. PAUD (Pendidikan Anak Usia Dini). Jogjakarta : DIVA Press; 2009 